Sofija Adžić ${ }^{1}$

Dragan Stojić ${ }^{2}$
JEL: C61 D81 G11 L66 Q13

DOI: 10.5937/industrija42-5731

UDC:338.43:339.137.2(497.113)"2009/2013"

Original Scientific Paper

\title{
Fuzzy Models in Measuring Competitiveness of Agroindustry
}

\author{
Article history: \\ Received: 8 March 2014 \\ Sent for revision: 21 March 2014 \\ Received in revised form: 22 April 2014 \\ Accepted: 27 April 2014 \\ Available online: 1 July 2014
}

\begin{abstract}
Over the past three decades, competitiveness has become an integral part of modern management and business development. The authors observe 18 enterprises in Vojvodina in the period 2009-2013 from Agriculture and Manufacturing sectors and measure their competitiveness based on the involvement of intellectual capital. The authors also propose the construction of a portfolio by solving the multiple criteria optimization problem. Fuzzy methodology has been applied: yields are modeled with trapezoidal fuzzy numbers, and the risk is measured by semi-deviation. Results of the study indicate a deviation from the Markowitz model which assumes that the yields are normally distributed, and that the appropriate risk measure is the variance of returns. Portfolios obtained by fuzzy methodology are characterized by higher values of intellectual capital, when compared to its counterparts obtained from Markowitz optimization.
\end{abstract}

Keywords: Portfolio;Optimization;Enterprise;Competition;Agroindustry.

\section{Fazi modeli za merenje konkurentnosti u agroindustriji}

Apstrakt: Konkurentnost je u protekle tri decenije sastavni deo modernog upravljanja razvojem i poslovanjem. Autori posmatraju 18 vojvođanskih preduzeća u periodu 2009-2013 iz sektora poljoprivrede i prerađivačke industrije i mere njihovu konkurentnost na osnovu angažovanosti intelektualnog kapitala. Autori dalje predlažu konstrukciju portfelja rešavanjem višekriterijumskog optimizacionog problema. Primenjena je fazi metodologija, prinosi su modelovani trapezoidnim fazi brojevima, a rizik se meri semi-devijacijom.

\footnotetext{
${ }^{1}$ University of Novi Sad, Faculty of Economics Subotica, Srbija

${ }^{2}$ University of Novi Sad, Faculty of Economics Subotica, Srbija, stojicd@ef.uns.ac.rs 
Adžić S., Stojić D.: Fuzzy Models in Measuring Competitiveness of Agroindustry

Rezultati studije ukazuju na odstupanje u odnosu na Markowitzev model koji podrazumeva da su prinosi normalno raspoređeni, pri čemu je varijansa adekvatna mera rizika. Portfelje dobijene fazi metodologijom čine kompanije sa većim vrednostima intelektualnog kapitala u odnosu na kompanije koje su dobijene rešavanjem Markowitzevog problema.

Ključne reči: Portfolio, optimizacija, preduzeća , konkurencija , agroindustrija.

\section{Introduction and literature review}

The problem of optimization is omnipresent in numerous fields of human activities, especially in field of economics and finance (see e.g. Craven \& Sardar, 2005, Hirschey, 2009 and Luptačik, 2010) the fundamental goal of optimization is to search for the best among all available alternative solutions to various problems, within posed limitations. Common problems in economics that are solved by means of optimization include, but are not limited to costs, level of quality for products and services, investment portfolios, competitiveness.

The problem of competitiveness is being analyzed on various levels of socioeconomic organization, from production processes in individual enterprises, through sectors and clusters to national states and international regions.

Back in 2009, the European commission has redefined the concept of competitiveness as a synthetic indicator of economic performances of a member state, which is expressed in the ability to ensure rising living standards and employment for all citizens who want to work (EC, 2010, p.18). In the short run competitiveness is focused on increasing the rate of GDP growth and the profitability of a company. However, in the long run, countries should strive towards prosperity, and progress (Garelli, 2008).

There is no unique approach to measuring competitiveness. Siggel (2006) divides concepts for measuring competitiveness according to focus of observations into: concepts for measuring competitiveness at macro and micro level. Furthermore, Siggel determined their structure by dividing them into one-dimensional, two-dimensional and multidimensional, static and dynamic, deterministic and stochastic, positive and normative, ex-post and ex-ante, etc. In this paper, we measure the competitiveness of the companies by their ability to generate added value.

The main objective for the investor is to maximize returns while minimizing risk. However, this goal is difficult to achieve, bearing in mind the mutual dependence of risk and return that is typically measured by Sharpe ratio (see, e.g. Kapil, 2011, Brigham \& Houston, 2012). Markowitz (1952), Nobel laureate, was the first who theoretically demonstrated that the creation of the diversified portfolio, as opposed to the individual selection of appealing stocks 
Adžić S., Stojić D.: Fuzzy Models in Measuring Competitiveness of Agroindustry

could better reduce the risk of investment, and was the first who pointed out the necessity of compromise between risk and return in the portfolio. Given his work and later works by other authors, investors tend to form investment portfolios as a basket of different investments to diversify risk and return. Optimization of the investments represents the efforts of investors to form an investment portfolio that will enable the achievement of maximizing returns with a level of investment risk they are comfortable with (see e.g. Jones 2010, Anderson et al., 2012). After Markowitz's paper, the investigation of choosing the optimal portfolio shifted towards relaxation of the original assumptions. Two groups of methods of solving the optimization problem are probabilistic and possibilistic (fuzzy) programming. The problems are posed as singlecriterion (minimizing risk with a fixed level of return and the establishment of an effective border) and multiple criteria (minimizing risk while maximizing returns, maximizing dividends, etc.). In this paper we apply the method of multiple criteria fuzzy programming to solve the problem of optimal portfolio selection. We compare results with Markowitz model applied to sectors of agriculture and manufacturing. Multiple criteria enable us to choose companies with higher competitiveness performances when compared to those chosen by Markowitz portfolio.

Markowitz's model dates back to 1952 . The model is also called the V-model in stochastic programming. In order to obtain the Pareto optimal solution to the problem, the variance (as a measure of risk) is minimized at a constant level of expected return:

minimize $\quad V\left(\sum c_{j} x_{j}\right)=\Sigma \sigma_{j}^{2} x_{j}$

such that $\quad E\left(\Sigma c_{j} x_{j}\right)=\Sigma m_{j} x_{j}=T$

$$
\Sigma x_{j}=1, x_{j} \geq 0, j=1,2, \ldots n .
$$

The weakness of this model lies in the fact that by choosing small values of $T$, the solution requires disproportionately large investments in inefficient stocks with small variance.

Although the theory of probability still serves as the main tool in the analysis of uncertainty in finance, certain factors that affect markets are not stochastic in their nature. These are linguistic descriptions of financial variables that characterize the two types of uncertainty: ambiguity, for example 'yield around $12 \%$ ' and vagueness, in the sense of unclear boundaries, e.g. 'high risk'. Fuzzy mathematical programming is developed out of the need for adequate solving of optimization problems containing such ambiguities. Brief overview of the literature using fuzzy methodology in solving the problem of the optimal portfolio follows. 
Adžić S., Stojić D.: Fuzzy Models in Measuring Competitiveness of Agroindustry

\subsection{Fuzzy optimization in literature}

Lin \& Liu (2008) notice that the solutions of linear and quadratic models of portfolio selection are real numbers, and therefore could hardly be applied in practice because every purchase means there is a minimum amount of the transaction. Previous methods which considered the minimum amount of transactions were based on linear models, but none examined this problem in Markowitz optimization model. The authors provide three possible models for portfolio selection with minimum amounts of purchased shares and develop appropriate genetic algorithms (GA) to obtain solutions. The results show that the portfolios obtained are very close to the portfolios on the efficient frontier, suggesting that the proposed methodology can produce nearly optimal and achievable solution in real-time.

Vercher et al. (2007) propose two models for selection of a portfolio with the downward risk measure, i.e. semi variance, with the restriction that the yield must not be less than the present value. Yields on individual assets are approximated by trapezoidal fuzzy numbers of the same shape, and the expected return and risk are evaluated by mean interval values. The authors used order relations for dealing with the interval estimates. Vercher (2008) further discusses a new model for solving the above set of problems and proposed SIP (semi-infinite programming) with weak constraints. Yield estimates were obtained using only historical data, while the risk is assessed as in previous work. Gupta et al. (2008) used fuzzy methodology in the assessment of the expected returns, liquidity and risk.

Fuzzy methodology allows the inclusion of subjective characteristics of the portfolio selection model, which formed the basis for the expression of individual preferences of investors. Different levels of investors' aspirations are modeled with $S$ shape membership function. The authors generalize MV (mean-variance) model using the given membership functions and semiabsolute deviation. The model is flexible in the sense that if the client is not satisfied with the proposed solutions, it is possible to generate new solutions (portfolios) by varying the values of S-function parameters. The effectiveness of the solution is verified through two stages to guarantee a fuzzy efficient solution.

Li et al. (2010) observed asymmetry in the distributions of the portfolio returns, since for the same value of the expected return and variance, investors prefer the portfolio with greater asymmetry. The authors define the coefficient of asymmetry of the fuzzy variables and examine its properties. The authors propose an extension to the fuzzy MV model - MV model with asymmetry. In solving the problem they construct a GA (generic algorithm) for the integration of fuzzy simulation. A similar problem is solved in Bhattacharyya et al. (2011), 
Adžić S., Stojić D.: Fuzzy Models in Measuring Competitiveness of Agroindustry

where three models were recognized and solved using fuzzy simulations with GA in creating a powerful hybrid intelligent algorithm (HIA).

Tanaka \& Guo (1999) identify two types of possibilistic distributions, upper and lower distribution which they use to assess the opinion of experts in the problem of portfolio selection. Portfolio selection is formulated as a quadratic problem. The authors conclude that the return on a portfolio, measured by lower possibilistic distribution has a smaller range than the yield obtained from the upper possibilistic distribution. Authors define a possibilistic risk as an interval between returns obtained with these two distributions, and use it for measuring the uncertainty in real-world situations in investing.

\section{The model setting}

The survey encompasses 18 companies from the Vojvodina region in the period 2009-2013, five from the sector of the Agriculture, Forestry and Fishing, and 13 from the Manufacturing industry whose shares are traded on the regulated market ${ }^{3}$ of the Belgrade stock exchange (BSE). The list of companies is provided in Appendix 1. Data was collected from the Belgrade stock exchange website, both for share prices and financial statement figures.

The rationale behind multiple criteria portfolio selection model is that the expected return and risk do not include all the available and necessary information for making an investment decision. The inclusion of additional criteria could modify a decision in terms of the selection of a portfolio that does not dominate in MV setting, but it makes up for excellent performance on other criteria, and is dominant in the multiple criteria setting. Following the work of Gupta et al (2008), the criteria used are as follows: short-term and long-term returns and risk, while for the first time we introduce such restrictions as intellectual efficiency and effectiveness of physical capital, as measures of firm's competitiveness. The last two criteria used fundamental indicators of financial statements of surveyed companies and it is interesting to observe how these additional criteria correct the optimal portfolio.

We adopt following notation:

$r_{i}$ - return on stocks of the $i$-th company, $i=1,2, \ldots, n$. We distinguish between two types of returns: annual $-r_{i}^{12}$, and quarterly $-r_{i}^{3} ; x_{i}$ - share of total assets invested in stock $\mathrm{i} ; \mathrm{y}_{\mathrm{i}}$ - indicator of portfolio membership of stock $\mathrm{i}$, having value 1 if stock belongs to the portfolio and 0 otherwise

It is now possible to formulate objectives and restrictions:

\footnotetext{
${ }^{3}$ We omitted companies traded in MTP market due to illiquidity issues.
} 
Adžić S., Stojić D.: Fuzzy Models in Measuring Competitiveness of Agroindustry

The yield on the risky assets is modeled with trapezoidal fuzzy numbers, which emphasize the uncertainty of the financial markets, as well as imprecise and incomplete information at disposal. For a more detailed insight into the theory of fuzzy sets to see the fundamental works of: Zadeh (1965), Dubois Prade $(1980,1987)$. Trapezoidal fuzzy number presented in Figure 1 is denoted by $A=(a, b, \alpha, \beta)$ with a membership function given by:

$$
\mu_{A}(x)=\left\{\begin{array}{lr}
1-\frac{a-x}{\alpha}, & a-\alpha \leq x \leq \alpha \\
1 \quad, a \leq x \leq b . \\
1-\frac{x-b}{\beta}, b \leq x \leq b+\beta
\end{array} .\right.
$$

Let $r_{i}=\left(a_{i}, b_{i}, a_{i}, \beta_{i}\right)$ be the return on stock $i$ in portfolio. For a portfolio of $n$ risky assets, $\mathbf{x}=\left(\mathrm{x}_{1}, \ldots, \mathrm{x}_{\mathrm{n}}\right)$, fuzzy return is given by:

$\Pi s(x)=r_{1} x_{1}+\ldots+r_{n} x_{n}=\left(\sum a_{j} x_{j}, \Sigma b_{j} x_{j}, \Sigma a_{j} x_{j} \Sigma \beta_{j} x_{j}\right)=(A(x), B(x), \alpha(x), \beta(x))$.

Figure 1. Membership function of a trapezoidal fuzzy number

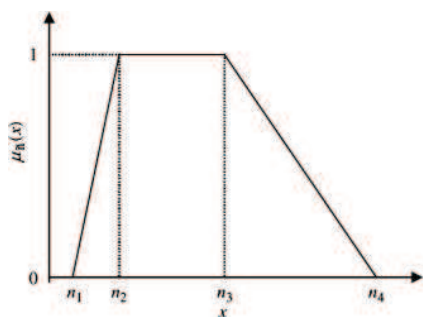

Source: Author

The expected value of the return on a portfolio $\Pi$ given by a trapezoidal fuzzy number is defined by Dubois \& Prade (1987) as an interval $\left[E^{*}, E^{*}\right]=[A(x)$ $\alpha(x) / 2, B(x)+\beta(x) / 2$ ]. Defuzzification by means of center of gravity (COG) gives us the arithmetic mean of this interval, $E(\Pi)=\Sigma 1 / 2\left[a_{i}+b_{i}+1 / 2\left(\beta_{i}-a_{i}\right)\right] x_{i}$, as assessment of the expected return on a portfolio that maximizes $\Pi$. Choosing specific values $a, b, \alpha$ and $\beta$, as well as the form of the membership functions fuzzy numbers to describe the yield of each action is somewhat arbitrary. Following the work of Vercher (2007) for the core [a, b], we use 40th, i.e. 60 th percentile of the distribution of the yield obtained from historical data, and the ranges of $\alpha$ and $\beta$ differences between 40th and 5th, i.e. 95th and 60th percentile. Different choices are possible, for details see Klir \& Yuan (1995). 
Adžić S., Stojić D.: Fuzzy Models in Measuring Competitiveness of Agroindustry

Portfolio risk is measured by the semi-absolute deviation of returns on portfolio $\mathbf{x}$ below the expected return. We believe that deviations above the expected return cannot be treated as risky, but desirable, therefore they do not add to the amount of total risk. The measure of 'lower risk' describes the preferences of investors in a more realistic way for penalizing only negative deviations from the expected return. Stevenson (2001) points out the validity of using such a measure in the case of emerging markets where returns are not normally distributed. Average semi-absolute deviation of returns on portfolio $\mathbf{x}$ was proposed by Speranza (1993):

$\sigma^{\prime}(\Pi)=E(\max \{0, E(\Pi)-\Pi\})$.

One can easily show that the interval containing semi-deviation is of the following form:

$\sigma^{\prime}(\Pi)=[0, B(x)-A(x)+1 / 2(\alpha(x)+\beta(x))]$, and that after defuzzyfication we obtain:

$\sigma^{\prime}(\Pi)=\Sigma 1 / 2\left[b_{i}-a_{i}+1 / 2\left(\beta_{i}+a_{i}\right)\right] x_{i}$.

Budget constraints: $\Sigma x_{i}=1$; short selling is prohibited: $x_{i} \geq 0, i=1,2, \ldots, n$.

Maximum and minimum value invested in a specific stock:

$l_{i} \leq x_{i} \leq u i, i=1,2, \ldots, n$.

Maximum and minimum share of wealth depend on a number of fundamental factors: trends in the industry, the minimum number of shares that must be purchased, small capitalization companies, just to name few.

The efficiency of intellectual capital is a fundamental indicator calculated as the sum of human capital efficiency (HCE) and structural capital efficiency (SCE). Lee (2010) defines the efficiency of human capital as a proportion of the information converted to wealth. As the amount of information exchanged in each of the surveyed companies is not available, without diminishing the importance of Lee's theoretical approach, we opt for the previously introduced definition that uses available data from financial statements. HCE measures the quantity of value added (VA) from each monetary unit invested in employees (BPZ). Structural capital (SC) is the result of human capital in the past, and its effectiveness is reflected in the share of the created added value:

ICEi $=\mathrm{VAi} / \mathrm{BPZi}+\mathrm{SCi} / \mathrm{VAi}$. We expect that highly efficient companies (ICE > 2) generate added value more easily.

Intellectual capital generates value in conjunction with the physical and financial capital. The effectiveness of the use of physical capital, CEE is the share of value added in total assets (TA): 
Adžić S., Stojić D.: Fuzzy Models in Measuring Competitiveness of Agroindustry

$\mathrm{CEE}=\mathrm{VA} / \mathrm{TA} . \mathrm{CEE}$ shows the amount of value added created from each monetary unit invested in physical capital. The sum of the aforementioned efficiencies of the portfolio $x$ is given by:

$\operatorname{VAIC}(\mathrm{x})=\operatorname{VAIC}_{1} \mathrm{x}_{1}+\operatorname{VAIC}_{2} \mathrm{x}_{2}+\ldots+\operatorname{VAIC}_{n} \mathrm{x}_{n}$

Based on the previously exposed we are able to formulate the problem of choosing the optimal portfolio as follows:

$\operatorname{Max} \Pi s(\mathrm{x})=\sum \mathrm{r}^{12} \mathrm{x}_{\mathrm{i}}$

$\operatorname{Max} \Pi s(x)=\sum r^{3} x_{i}$

$\operatorname{Min} \sigma^{\prime}(\Pi)=\Sigma 1 / 2\left[b_{i}-a_{i}+1 / 2\left(\beta_{i}+\alpha_{i}\right)\right] x_{i}$

Such that:

$\sum x_{i}=1$,

$\mathrm{l}_{\mathrm{i}} \leq \mathrm{x}_{\mathrm{i}} \leq \mathrm{u}_{\mathrm{i}}, \mathrm{i}=1,2, \ldots, \mathrm{n}$,

$\operatorname{VAIC}(x)=\sum \operatorname{VAIC}_{\mathrm{i}} \mathrm{x}_{\mathrm{i}} \geq 2$,

$x_{i} \geq 0, i=1,2, \ldots, n$,

\section{Results and discussion}

In solving the optimization problem we used the application Lingo 13.0. Program script is given in the Appendix 2. Chart 1 presents the efficient frontier as a solution to Markowitz optimization problem. Correlations between returns vary significantly from negative to moderately positive, even for the companies from the same sector, which explains the low total variance of the portfolio. With the increase in the expected return the number of shares in the portfolio decreases, as shown in Table 1.

Optimal portfolios include two companies from the agriculture sector (2 and 4 ), and on average $75 \%$ of wealth is invested in the manufacturing sector. With the increase in the expected return of investment, the share of manufacturing industry in portfolio continues to rise, which can be explained by the higher average expected returns in the sector. The main advantage of Markowitz model is the use of covariance matrix, i.e. information about the interdependence of stocks that leads to minimization of the total risk measured by standard deviation of the portfolio. 
Adžić S., Stojić D.: Fuzzy Models in Measuring Competitiveness of Agroindustry

Figure 2. Portfolios on the efficient frontier - Markowitz optimization

Expected return

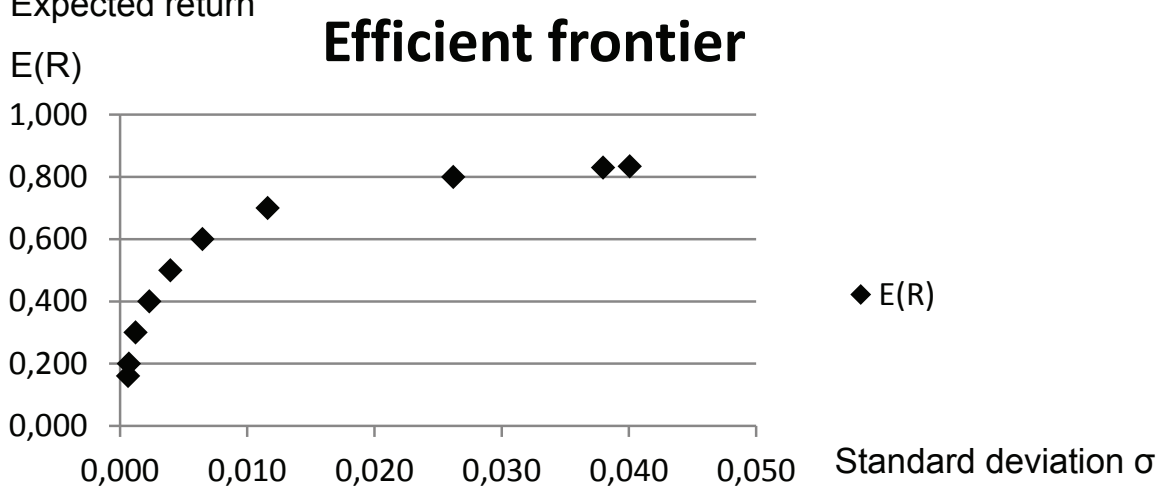

Source: Author

Table 1. Structure of efficient portfolios

\begin{tabular}{|c|c|c|c|c|c|c|c|c|c|c|c|c|}
\hline \multirow[t]{2}{*}{ Return } & \multicolumn{12}{|c|}{ Company } \\
\hline & \multicolumn{12}{|c|}{ Share of individual stocks } \\
\hline \multirow[t]{2}{*}{0,149} & 1 & 2 & 4 & 6 & 8 & 9 & 10 & 11 & 13 & 14 & 16 & 17 \\
\hline &, 0031 &, 1744 &, 0716 &, 0357 &, 0571 & \begin{tabular}{|l|}
, 053 \\
7
\end{tabular} &, 0363 & ,392 &, 0785 &, 0083 &, 0012 &, 0885 \\
\hline \multirow[t]{2}{*}{0,2} & 2 & 4 & 6 & 8 & 9 & 10 & 11 & 13 & 14 & 17 & & \\
\hline &, 143 &, 0848 &, 0452 &, 08 &, 0522 & $\begin{array}{l}, 051 \\
1\end{array}$ &, 335 &, 1258 &, 0047 & 0,0781 & & \\
\hline \multirow[t]{2}{*}{0,3} & 2 & 4 & 6 & 8 & 9 & 10 & 11 & 13 & 17 & & & \\
\hline &, 093 &, 11 &, 0583 &, 126 &, 0467 & $\begin{array}{l}, 079 \\
5\end{array}$ &, 215 &, 218 &, 0532 & & & \\
\hline \multirow[t]{2}{*}{0,4} & 2 & 4 & 6 & 8 & 9 & 10 & 11 & 13 & 17 & & & \\
\hline &, 061 &, 134 &, 0605 &, 175 &, 0385 & 106 & ,0882 &, 309 & 0277 & & & \\
\hline \multirow[t]{2}{*}{0,5} & 2 & 4 & 6 & 8 & 9 & 10 & 12 & 13 & 17 & & & \\
\hline &, 007 &, 156 &, 0566 & ,2208 &, 0235 & $\begin{array}{l}114 \\
4\end{array}$ &, 0162 & ,398 &, 007 & & & \\
\hline \multirow[t]{2}{*}{0,6} & 4 & 6 & 8 & 12 & 13 & 17 & & & & & & \\
\hline &, 1539 &, 0472 & ,2882 & ,0334 &, 4707 &, 007 & & & & & & \\
\hline \multirow[t]{2}{*}{0,7} & 4 & 8 & 12 & 13 & 17 & & & & & & & \\
\hline &, 0661 & ,3945 & ,008 &, 5294 &, 002 & & & & & & & \\
\hline \multirow[t]{2}{*}{0,8} & 8 & 13 & & & & & & & & & & \\
\hline &, 33 & ,67 & & & & & & & & & & \\
\hline
\end{tabular}

Source: Author 
Adžić S., Stojić D.: Fuzzy Models in Measuring Competitiveness of Agroindustry

The main drawback of this approach is that the observed returns (both annual and quarterly) are not normally distributed for any stock in the survey, thus the extreme returns (positive and negative) are more likely than a normal distribution would predict. Distribution of returns is asymmetric, which is not taken into account when solving Markowitz's problem. Previously presented fuzzy methodology is an attempt to overcome this shortcoming, and the results of the optimization problem posed and solved as a fuzzy mathematical program are given in Tables 2 and 3 . Table 3 presents the share of wealth invested in each stock of the optimal portfolio. We observe continuous changes in ratios, with no significant jumps.

Table 2. Basic features of optimal portfolios: returns, risk and competitiveness

\begin{tabular}{|l|l|l|l|l|l|l|l|}
\hline Risk & $\begin{array}{c}\text { Annual } \\
\text { return }\end{array}$ & $\begin{array}{c}\text { Quarterly } \\
\text { return }\end{array}$ & VAIC & Risk & $\begin{array}{c}\text { Annual } \\
\text { return }\end{array}$ & $\begin{array}{c}\text { Quarterly } \\
\text { return }\end{array}$ & VAIC \\
\hline 0,34 & 0,0699 & 0,0827 & 3,173 & 0,60 & 0,4857 & 0,1739 & 3,658 \\
\hline 0,35 & 0,1356 & 0,1000 & 3,405 & 0,65 & 0,5426 & 0,2048 & 3,717 \\
\hline 0,40 & 0,2453 & 0,1117 & 3,575 & 0,70 & 0,5988 & 0,2369 & 3,407 \\
\hline 0,45 & 0,3072 & 0,1354 & 3,600 & 0,75 & 0,6207 & 0,2821 & 3,455 \\
\hline 0,50 & 0,3674 & 0,1436 & 3,610 & 0,80 & 0,6258 & 0,2769 & 3,335 \\
\hline 0,55 & 0,4276 & 0,1519 & 3,619 & 0,85 & 0,6258 & 0,2769 & 3,335 \\
\hline
\end{tabular}

Source: Author

Table 2 contains the basic features of the optimal portfolio, while Figure 2 represents the efficient frontier of fuzzy optimal portfolios. With the increase of the level of risk measured by the absolute semi-deviation, both long-term and short-term returns $\mathrm{r} 12$ and $\mathrm{r} 3$ increased. The growth of returns stops for risk levels greater than 0,8 , reaching the asymptotic levels of $62,58 \%$ for long-term and $27,69 \%$ for short-term returns. In the observed range of risks, the competitiveness of portfolio, obtained as a linear combination of the competitiveness of individual enterprises has a form of quadratic function and reaches a maximum at the level of risk of 0,65 . 9 out of 11 companies are present in all medium level risk $(0,4-0,7)$ portfolios.

Compared with the Markowitz portfolio there has been a greater share of companies in the sectors of agriculture, forestry and fishing. The share is on average about $40 \%$, which can be explained by positive asymmetric distributions of annual returns of 4 out of 5 companies from the sector, which are modeled adequately by trapezoidal fuzzy numbers. The same holds for the distribution of quarterly returns that are also maximized in finding the optimal portfolio. The competitiveness of the portfolio measured by the efficiency of intellectual and physical capital is around 3.5, which means that the selected companies are characterized by feature to easily generate added value. 
Adžić S., Stojić D.: Fuzzy Models in Measuring Competitiveness of Agroindustry

Table 3. The structure of portfolios (Pareto optimal solutions) for different risk levels

\begin{tabular}{|c|c|c|c|c|c|c|c|c|c|c|c|}
\hline \multirow[t]{2}{*}{ Risk } & \multicolumn{10}{|c|}{ Company } & \\
\hline & \multicolumn{10}{|c|}{ Share of individual stocks } & \\
\hline \multirow[t]{2}{*}{0,34} & 1 & 2 & 3 & 4 & 5 & 6 & 7 & 10 & 12 & 15 & 17 \\
\hline & 0,005 & 0,10 & 0,095 & 0,10 & 0,10 & 0,10 & 0,10 & 0,10 & 0,10 & 0,10 & 0,10 \\
\hline \multirow[t]{2}{*}{0,35} & 1 & 2 & 4 & 5 & 6 & 7 & 10 & 12 & 14 & 15 & 17 \\
\hline & 0,10 & 0,10 & 0,10 & 0,10 & 0,10 & 0,10 & 0,094 & 0,10 & 0,006 & 0,10 & 0,10 \\
\hline \multirow[t]{2}{*}{0,40} & 1 & 2 & 4 & 5 & 6 & 7 & 10 & 11 & 12 & 14 & 17 \\
\hline & 0,10 & 0,10 & 0,10 & 0,049 & 0,10 & 0,10 & 0,051 & 0,10 & 0,025 & 0,10 & 0,10 \\
\hline \multirow[t]{2}{*}{0,45} & 1 & 2 & 4 & 6 & 7 & 10 & 11 & 12 & 13 & 14 & 17 \\
\hline & 0,10 & 0,10 & 0,10 & 0,10 & 0,10 & 0,075 & 0,10 & 0,10 & 0,025 & 0,10 & 0,10 \\
\hline \multirow[t]{2}{*}{0,50} & 1 & 2 & 4 & 6 & 7 & 10 & 11 & 12 & 13 & 14 & 17 \\
\hline & 0,10 & 0,10 & 0,10 & 0,10 & 0,10 & 0,044 & 0,10 & 0,10 & 0,056 & 0,10 & 0,10 \\
\hline \multirow[t]{2}{*}{0,55} & 1 & 2 & 4 & 6 & 7 & 10 & 11 & 12 & 13 & 14 & 17 \\
\hline & 0,10 & 0,10 & 0,10 & 0,10 & 0,10 & 0,012 & 0,10 & 0,10 & 0,088 & 0,10 & 0,10 \\
\hline \multirow[t]{2}{*}{0,60} & 1 & 2 & 4 & 6 & 7 & 8 & 11 & 12 & 13 & 14 & 17 \\
\hline & 0,10 & 0,10 & 0,10 & 0,072 & 0,10 & 0,028 & 0,10 & 0,10 & 0,10 & 0,10 & 0,10 \\
\hline \multirow[t]{2}{*}{0,65} & 1 & 2 & 4 & 6 & 7 & 8 & 11 & 12 & 13 & 14 & 17 \\
\hline & 0,10 & 0,10 & 0,10 & 0,026 & 0,10 & 0,074 & 0,10 & 0,10 & 0,10 & 0,10 & 0,10 \\
\hline \multirow[t]{2}{*}{0,70} & 1 & 2 & 4 & 6 & 7 & 8 & 11 & 12 & 13 & 14 & 17 \\
\hline & 0,10 & 0,10 & 0,025 & 0,075 & 0,10 & 0,10 & 0,10 & 0,10 & 0,10 & 0,10 & 0,10 \\
\hline \multirow[t]{2}{*}{0,75} & 1 & 2 & 6 & 7 & 8 & 9 & 11 & 12 & 13 & 14 & 16 \\
\hline & 0,10 & 0,082 & 0,10 & 0,10 & 0,10 & 0,10 & 0,10 & 0,10 & 0,10 & 0,10 & 0,018 \\
\hline \multirow[t]{2}{*}{0,80} & 1 & 6 & 7 & 8 & 9 & 11 & 12 & 13 & 14 & 16 & \\
\hline & 0,10 & 0,10 & 0,10 & 0,10 & 0,10 & 0,10 & 0,10 & 0,10 & 0,10 & 0,10 & \\
\hline \multirow[t]{2}{*}{0,85} & 1 & 6 & 7 & 8 & 9 & 11 & 12 & 13 & 14 & 16 & \\
\hline & 0,10 & 0,10 & 0,10 & 0,10 & 0,10 & 0,10 & 0,10 & 0,10 & 0,10 & 0,10 & \\
\hline
\end{tabular}

Source: Author

VAIC coefficients for Markowitz portfolios are somewhat lesser and can be found in the interval 3,06 to 3,49 . 
Adžić S., Stojić D.: Fuzzy Models in Measuring Competitiveness of Agroindustry

Figure 3. Portfolios on the efficient frontier - fuzzy mathematical program

\section{Expected return $E(R) \quad$ Efficient frontier}

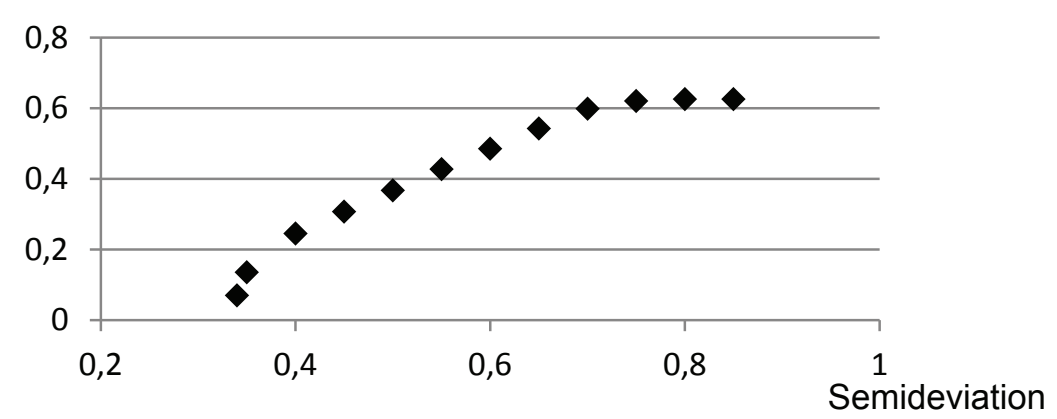

Source: Author

\section{Concluding remarks}

Fuzzy methodology is an adequate method for modeling events which in addition to the stochastic nature possess as well a subjective character in form of investors' expectations who with their activities on the market can affect the values and states of events in question. In this paper we have presented a model for measuring the competitiveness of companies in the field of agriculture and manufacturing industry of Vojvodina and also application in solving the problem of multiple criteria portfolio selection. A comparison with the results of classical Markowitz optimization problem was presented.

Possible shortcomings of the paper could lie in the fact that only a small number of variables was used - both as constraints and objective functions, but the goal was primarily to incorporate into portfolio the figures from financial statements that can be used to measure the competitiveness of companies. The disadvantage of the methodology itself is that, although the semi absolute deviation is an appropriate measure of risk, it is calculated as a linear combination of individual risk, and therefore to obtain adequate information it would be optimal to combine different methods, both probabilistic and possibilistic.

\section{References}

Anderson, D. R., Sweeney, D. J., Williams, T. A., Camm, J. D., \& Martin, K. (2012). An Introduction to Management Science: Quantitative Approaches to Decision Making. South-Western Cengage Learning, Mason, $\mathrm{OH}$.

Bhattacharyya, R., Kar, S., \& Majumder, D. D. (2011). Fuzzy mean-varianceskewness portfolio selection models by interval analysis. Computers \& Mathematics with Applications, 61(1), 126-137. 
Adžić S., Stojić D.: Fuzzy Models in Measuring Competitiveness of Agroindustry

Brigham, E. F., \& Houston, J. F. (2012). Fundamentals of Financial Management. South-Western Cengage Learning, Mason, $\mathrm{OH}$.

Craven, B. D., \& Sardar, M. N. I. (2005). Optimization in Economics and Finance: Some Advances in Non-Linear, Dynamic, Multi-Criteria and Stochastic Models. Springer, AA Dordrecth, The Netherlands.

Dubois, D., \& Prade, H. (1980). Systems of linear fuzzy constraints. Fuzzy sets and systems, 3(1), 37-48.

Dubois, D., \& Prade, H. (1987). The mean value of a fuzzy number. Fuzzy sets and systems, 24 (3), 279-300.

Garelli, S. (2008). Competitiveness 20 years later. IMD World Competitiveness Yearbook (pp. 29-34). Lausanne, Switzerland.

Gupta, P., Mehlawat, M. K., \& Saxena, A. (2008). Asset portfolio optimization using fuzzy mathematical programming. Information Sciences, 178(6), 1734-1755.

Hirschey, M. (2009). Fundamental of Managerial Economics. South-Western Cengage Learning, Mason, $\mathrm{OH}$.

Jones, C. P. (2010). Investments Analysis and Management. John Wiley \& Sons, Hoboken, NY.

Kapil, S. (2011). Financial Management. Dorling Kindersley, Noida, India.

Klir, G. J., \& Yuan, B. (1995). Fuzzy sets and fuzzy logic: Theory and applications. Chapter 10, 280-331. Prentice hall New Jersey.

Lee, R. (2010). Information Filtering, Human Capital Efficiency and Economic Growth in Poor Neighborhoods. Canadian Journal of Regional Science, 33(1), 71-82.

Li, X., Qin, Z., \& Kar, S. (2010). Mean-variance-skewness model for portfolio selection with fuzzy returns. European Journal of Operational Research, 202(1), 239-247.

Lin, C., \& Liu, Y. T. (2008). Genetic algorithms for portfolio selection problems with minimum transaction lots. European Journal of Operational Research, 185(1), 393404.

Luptačik, M. (2010). Springer Optimization and Its Applications: Mathematical Optmization and Economic Analysis. Springer Science+Business Media, LLC, New York, NY.

Markowitz, H. (1952). Portfolio Selection. The Journal of Finance, 7(1), 77-91.

Siggel, E. (2006). International Competitiveness and Comparative Advantage: A Survey and a Proposal for Measurement. Journal of Industry, Competition and Trade, 6(2), 137-159. doi:10.1007/s10842-006-8430-x

Speranza, M. G. (1993). Linear programming model for portfolio optimization. Finance, 14,107-123.

Stevenson, H. (2001). Emerging markets, downside risk and the asset allocation decision. Emerging markets review, 2, 50-66.

Tanaka, H., \& Guo, P. (1999). Portfolio selection based on upper and lower exponential possibility distributions. European Journal of Operational Research, 114(1), 115-126.

Vercher, E., Bermúdez, J. D., \& Segura, J. V. (2007). Fuzzy portfolio optimization under downside risk measures. Fuzzy Sets and Systems, 158(7), 769-782.

Vercher, E. (2008). Portfolios with fuzzy returns: Selection strategies based on semiinfinite programming. Journal of Computational and Applied Mathematics, 217(2), 381-393.

Zadeh, L. A. (1965). Fuzzy Sets. Information and Control, 8(3), 338-353. 
Adžić S., Stojić D.: Fuzzy Models in Measuring Competitiveness of Agroindustry

\section{Appendices}

Appendix 1 - List of companies

1 Ravnica AD, Bajmok

2 Pionir AD Srbobran

3 AD Doža Đerđ Bačka Topola

4 AD Poljoprivreda Novo Selo Orom

5 AD Agrovršac Vršac

6 AD Neoplanta Novi Sad

7 Sojaprotein AD Bečej

8 Dijamant AD Zrenjanin

9 AD Vital Vrbas

10 AD Mlekara Subotica

11 Veterinarski Zavod AD Subotica

12 Šecerana Crvenka AD Crvenka

13 AD Fabrika Šecera Šajkaška Žabalj

14 Te-To AD Senta

15 Duvanska AD Čoka

16 Albus AD Novi Sad

17 AD Radijator Zrenjanin

18 AD Banini Kikinda 
Adžić S., Stojić D.: Fuzzy Models in Measuring Competitiveness of Agroindustry

Appendix 2 Lingo code

sets:

asset/1..18/:rate12, dev12, rate3, dev3, ice, cee, alfa, beta, a, b, x;

endsets

data:

rate12= $0.2787081030 .10848368-0.368988989-0.150812299-0.21755959$

$\begin{array}{llllllll}0.167318665 & 0.334154 & 1.4038136 & 0.25836 & 0.094244 & 0.278582 & 0.6068598\end{array}$ $2.00164630 .75835-0.03536150 .17020 .129005-0.208245$;

$\operatorname{dev} 12=0.4744625 \quad 0.144625 \quad 0.38569375 \quad 0.1567375 \quad 0.20575 \quad 0.4432125$

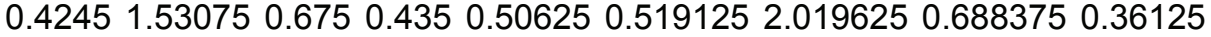
0.5596250 .319750 .50625 ;

rate3 $=0.403350 .02793 \quad 0.205239-0.09605-0.1136 \quad 0.096 \quad 0.1357 \quad 0.7683$ $0.49570 .23980 .11620 .273650 .502380 .012756-0.031-0.0350 .08-0.0731$;

$\operatorname{dev} 3=0.33665 \quad 0.1233750 .3517125 \quad 0.074475 \quad 0.099850 .3083750 .3285$ $\begin{array}{llllllll}0.67525 & 0.48375 & 0.327375 & 0.276 & 0.2885 & 0.4985 & 0.3180625 & 0.245625\end{array}$ 0.3916250 .23750 .339125 ;

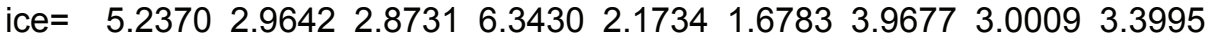
2.48102 .02103 .85712 .81344 .03311 .80961 .79181 .4419 2.1200;

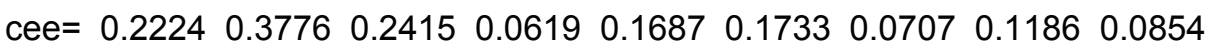
0.22560 .12450 .25730 .20100 .20940 .27120 .08880 .17730 .0856 ;

$\mathrm{ub}=0.1$;

rizik $=0.2$

intkap=2.5;

$\mathrm{ksi}=0.7$;

enddata

max=@sum(asset:rate12*x);

@sum(asset:rate $\left.{ }^{*} \mathrm{x}\right)>0.2$;

@sum(asset: $x)=1$;

@sum(asset:devx)<rizik;

@for(asset:@bnd(0,x,ub));

@sum(asset:x*(ice+cee))>intkap;

end 